\title{
Tropical cyclone activity and western North Atlantic stratification over the last millennium: a comparative review with viable connections
}

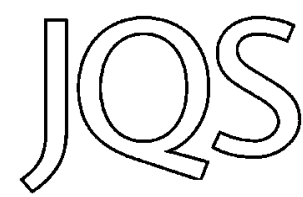

\author{
JONATHAN D. WOODRUFF, ${ }^{*}$ RYAN L. SRIVER ${ }^{2}$ and DAVID C. LUND ${ }^{3}$ \\ ${ }^{1}$ Department of Geosciences, University of Massachusetts, Amherst, Massachusetts, USA \\ ${ }^{2}$ Department of Geosciences, Pennsylvania State University, University Park, Pennsylvania, USA \\ ${ }^{3}$ Department of Earth and Environmental Sciences, University of Michigan, Ann Arbor, Michigan, USA \\ Received 2 May 2011; Revised 12 August 2011; Accepted 2 October 2011
}

\begin{abstract}
Tropical cyclones (TC) are recognized to modify the thermal structure of the upper ocean through the process of vertical mixing. Assessing the role this mixing plays in the overall stratification of the upper ocean is difficult, due to the relatively short and incomplete instrumental record. Proxy records for both TC landfalls and oceanographic stratification are preserved within the geological record and provide insight for how past changes in TC-induced mixing have potentially affected water column structure prior to the instrumental record. Here we provide the first comparison between previously published paleo-reconstructions of vertical ocean density and tropical cyclone activity from the western North Atlantic. A prominent lull in TC activity has been observed prior to approximately 1700 CE that extends back several centuries. This interval of low TC activity is shown to be concurrent with the timing of increased ocean stratification near Great Bahama Bank, potentially due in part to reduced TC-induced mixing. To test whether this relationship is feasible, we present numerical results from a coarse-resolution ocean general circulation model experiment isolating the effect of TC surface wind forcing on the upper ocean. An anomaly of roughly $0.12 \mathrm{~kg} \mathrm{~m}^{-3}$ in vertical stratification occurs above and below the mixed layer for model runs with and without TC mixing. This anomaly is roughly $25 \%$ of the entire paleo-density signal observed just prior to $1700 \mathrm{CE}$. These results suggest that TC mixing alone cannot completely explain the density anomaly observed prior to $1700 \mathrm{CE}$, but support TC variability as an important contributor to enhancing oceanic stratification during this interval. Copyright (C) 2011 John Wiley \& Sons, Ltd.
\end{abstract}

KEYWORDS: hurricanes; paleotempestology; paleoceanography; ocean; stratification; late Holocene.

\section{Introduction}

The relationship between tropical cyclone (TC) activity and climate variability continues to gain interest, largely because fundamental interactions remain poorly understood. Recent work has linked low-frequency variability in TC activity to changes in tropical sea surface temperature (Emanuel, 2005), and with observable increases in the number (Webster et al., 2005) and strength (Elsner et al., 2008) of the most intense storms since the onset of global satellite coverage around 1970 CE. However, model projections of future cyclone activity vary widely, and results suggest additional factors may be important within different climate change scenarios (Emanuel et al., 2008, 2010; Knutson et al., 2008). For example, new model results suggest that the annual number of Atlantic TCs is projected to decrease under continued anthropogenic warming, but the frequency of intense events (categories 4 and 5) may double (Bender et al., 2010). While there is strong evidence for a response in TC activity to changes in large-scale climate properties, TCs also appear to actively contribute to the dynamics of the climate system through ocean mixing.

Ocean mixing is an important physical process that regulates the global oceanic transport of heat, mass, and nutrients. Past findings indicate that TCs are a significant source of upper-ocean mixing in the Tropics (Sriver and Huber, 2007; Sriver et al., 2008). It has been hypothesized that this mixing is a major factor for maintaining the meridional overturning circulation and ocean heat transport (Emanuel, 2001), but recent modeling efforts suggest TCs play a more modest role for the present-day climate (e.g. Jansen and Ferrari, 2009; Sriver et al., 2010; Sriver and Huber, 2010), though TCs may be more important for large-scale oceanic transports in climate scenarios with temperature patterns warmer than

*Correspondence: J. D. Woodruff, as above.

E-mail: woodruff@geo.umass.edu present day (Brierley et al., 2009; Fedorov et al., 2010; Korty et al., 2008). Even though the impacts of TCs on high-latitude climate appear to be minimal, these events do appear to be important for tropical and subtropical ocean dynamics. New modeling results indicate that TC-induced ocean mixing influences upper ocean temperature and density patterns (Fedorov et al., 2010; Jansen and Ferrari, 2009; Sriver and Huber, 2010), due in part to the response of shallow subtropical overturning circulation to enhanced mixing in tropical cyclone regions.

In order to understand the nature of TC variability within the context of future climate change it is useful to establish a longterm record of TC information extending back to periods with climate factors different from the present day. Currently the lack of such long-term records is a major limitation in the field of TC climate variability. In the Atlantic basin, an official dataset exists containing track information and maximum wind speeds dating back to 1851 CE (Landsea et al., 2004), but the reliability of these data before the onset of satellite-based observations remains controversial (Landsea et al., 2010; Mann et al., 2007).

Proxies for both TC occurrences (e.g. Frappier et al., 2007a; Nott, 2004), and ocean stratification (e.g. Lund et al., 2006) exist within natural geological archives, and provide an additional resource for evaluating potential connections between TC activity and oceanic properties. To this end we provide a brief review of the state of knowledge with respect to both TC variability and ocean stratification in the western North Atlantic over the last millennium, framed in the context of potential interactions. Further, recent global climate modeling results by Sriver and Huber (2010) are presented to assess the sensitivity of vertical stratification in the western North Atlantic to TC mixing, and to provide a quantitative evaluation for the feasibility of TC variability as a driver for observed changes in paleo-stratification. 


\section{Tropical cyclone proxies}

Proxies for reconstructing TCs prior to the best-track dataset come from a diverse array of sources. Current compilations from ship logs, newspapers, government records and diaries extend back for several centuries both in the western North Atlantic (Boose et al., 2001, 2004; Chenoweth, 2006; Chenoweth and Divine, 2008; Garcia-Herrera et al., 2005; Ludlum, 1963; Mock, 2004, 2008), and western North Pacific (Chan and Shi, 2000; Fogarty et al., 2006; Garcia-Herrera et al., 2007; Grossman and Zaiki, 2007; Liu et al., 2001). Negative $\delta^{18} \mathrm{O}$ anomalies associated with TC precipitation are preserved in annually resolved speleothems and tree rings (Frappier et al., 2007b; Malmquist, 1997; Miller et al., 2006; Nott et al., 2007), and high terrestrial run-off by TCs also affecting the annual growth rate and luminescence of coral (Lough, 2007; Nyberg et al., 2007). TC-induced freshwater flooding events are also preserved within sedimentary archives (Grossman, 2001; Noren et al., 2002), with varved lacustrine chronologies allowing for annually resolved reconstructions of intense precipitation (Besonen et al., 2008). Additional to these historic and precipitation-based proxies, evidence of coastal inundation by TCs is often preserved within the geological record, including storm-induced beach ridges and scarps (Brooke et al., 2008; Buynevich et al., 2007; Nott, 2011; Nott et al., 2007, 2009; Nott and Hayne, 2001), cyclone-transported boulder deposits (Scheffers and Scheffers, 2006; Spiske et al., 2008; Suzuki et al., 2008; Yu et al., 2009; Zhao et al., 2009), and the existence of marine foraminifera within inland sediments (Hippensteel and Martin, 1999; Scott et al., 2003; Williams, 2010).

Along with the above-mentioned proxies, storm-induced overwash deposits preserved in coastal lagoons and salt marshes have proven to be an especially effective method for developing millennial-scale records of TC occurrences. Bottom sediments collected from these ordinarily sheltered areas are typically composed of fine-grained organic material. In contrast, during intense TC activity, associated storm surge and waves carry coarser sediment and marine material from the beach and near-shore into these back-barrier environments and deposit them as an anomalous event layer. Over time these storm layers are covered by accumulating fine-grained organic matter until the next high-energy storm event forms another anomalous deposit. The result is a preserved sedimentary record of TC-induced flooding at a site, identified typically from sediment cores using grain size analysis (e.g. Donnelly and Woodruff, 2007), percent inorganic content (e.g. Liu and Fearn, 2000), and/or the relative abundance of marine sourced material (e.g. Woodruff et al., 2009). Regions where overwash reconstructions currently exist for the western North Atlantic include the US east coast (Boldt et al., 2010; Donnelly et al., 2001a,b, 2004; Donnelly and Webb, 2004; Scileppi and Donnelly, 2007), the Gulf of Mexico (Liu and Fearn, 1993, 2000; McCloskey and Keller, 2009; Wallace and Anderson, 2010; Lane et al., 2011), and the Caribbean (Donnelly and Woodruff, 2007; Woodruff et al., 2008b). Although still limited in number, statistically significant trends in TC activity are beginning to emerge from these western North Atlantic paleoTC overwash records (Mann et al., 2009; Woodruff et al., 2008a). More specifically, prior to approximately $1700 \mathrm{CE}$ evidence exists for a period of decreased TC activity in the western North Atlantic extending back for several centuries. This lull in activity is roughly concurrent with the Little Ice Age (LIA), when independent climate proxies suggest more prevalent EI Niño like conditions, and reduced tropical North Atlantic sea surface temperatures (Donnelly and Woodruff, 2007; Mann et al., 2009), with both of these climatic trends generally serving to hinder TC activity in the western North Atlantic (e.g. Bove et al., 1998; Emanuel, 2005; Goldenberg et al., 2001; Gray, 1984). Prior to the LIA a period of increased TC activity similar to present levels occurs around roughly 1000 CE during an interval known as the Medieval Climate Anomaly (MCA), with this local maximum in TC activity likely driven by an increase in both sea surface temperature and a shift towards more La Niña-like conditions (Mann et al., 2009).

Regional records for the northern Caribbean at Vieques, Puerto Rico (Fig. 1), exhibit trends similar to those observed within the TC composite proxy record constructed for the entire western North Atlantic (Mann et al., 2009). More specifically, a period of reduced TC activity is observed between roughly 1700 and $1000 \mathrm{CE}$, bracketed between two periods of relatively higher TC activity both between $1700 \mathrm{CE}$ and present, and for an extended period of time prior to 1000 CE (Fig. 2A). A pattern of increased TC activity before $1000 \mathrm{CE}$, followed by reduced activity, is also observed both in overwash reconstructions from the northern Gulf Coast and from the New York region (Fig. 2A), together suggesting a concurrent shift to decreased TC activity following the MCA (Mann et al., 2009; Woodruff et al., 2008a). The most recent transition to increased activity following $1700 \mathrm{CE}$ is less evident in Gulf Coast records, but observed both at the Vieques and New York sites (Fig. 2A), potentially suggesting a digression between TC activity in the Gulf of Mexico and that in the open western North Atlantic (Liu and Fearn, 2000).

Reconstructions of TC wind damage from Puerto Rico also exhibit a marked increase in severe TC wind damage of F2 and F3 magnitude on the Fujita Scale (equivalent to approximately hurricane categories 3-5 intensity), beginning around $1700 \mathrm{CE}$ (Boose et al., 2004), and at roughly the same time when overwash reconstructions for storms of similar intensity at the Vieques site show a concurrent increase in TC counts (Fig. 2B). This historical-based reconstruction for Puerto Rico is almost certainly biased towards a gradual decrease in storm counts when extended toward the beginning of the record due to a decline in the number of historical documents available and a

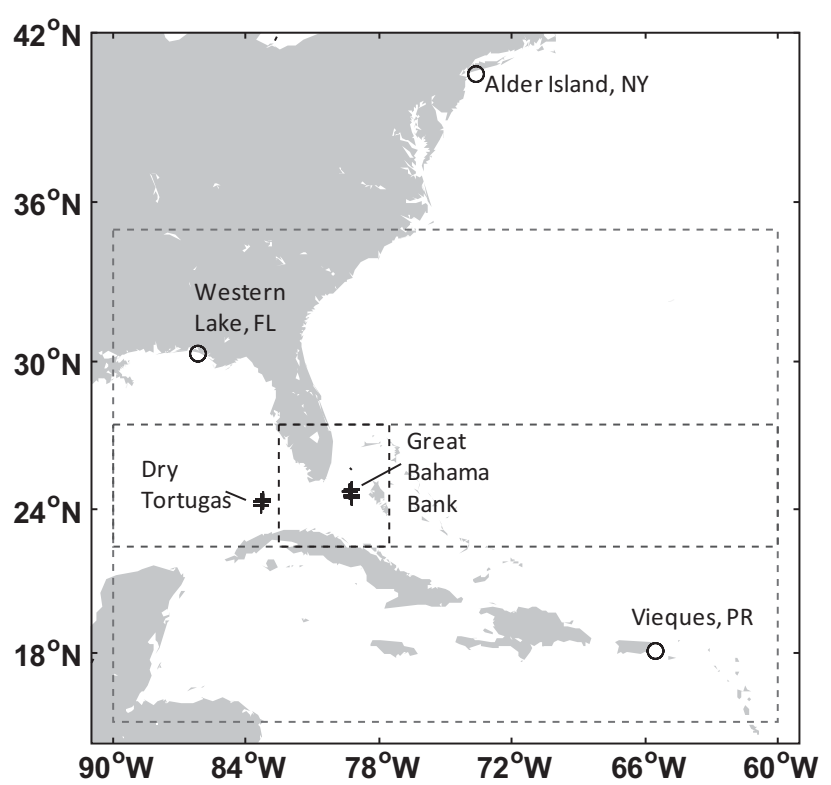

Figure 1. Site map with locations for presented paleo-TC (circles) and paleo-density (plus signs) reconstructions presented in Fig. 2. Dashed lines identify the boundaries of spatial averaging for model results presented in Fig. 3C, including the grid point enclosing Great Bahama Bank (black), the Gulf Stream region at the Bahaman latitude (dark gray), and the larger western boundary region (light gray). 


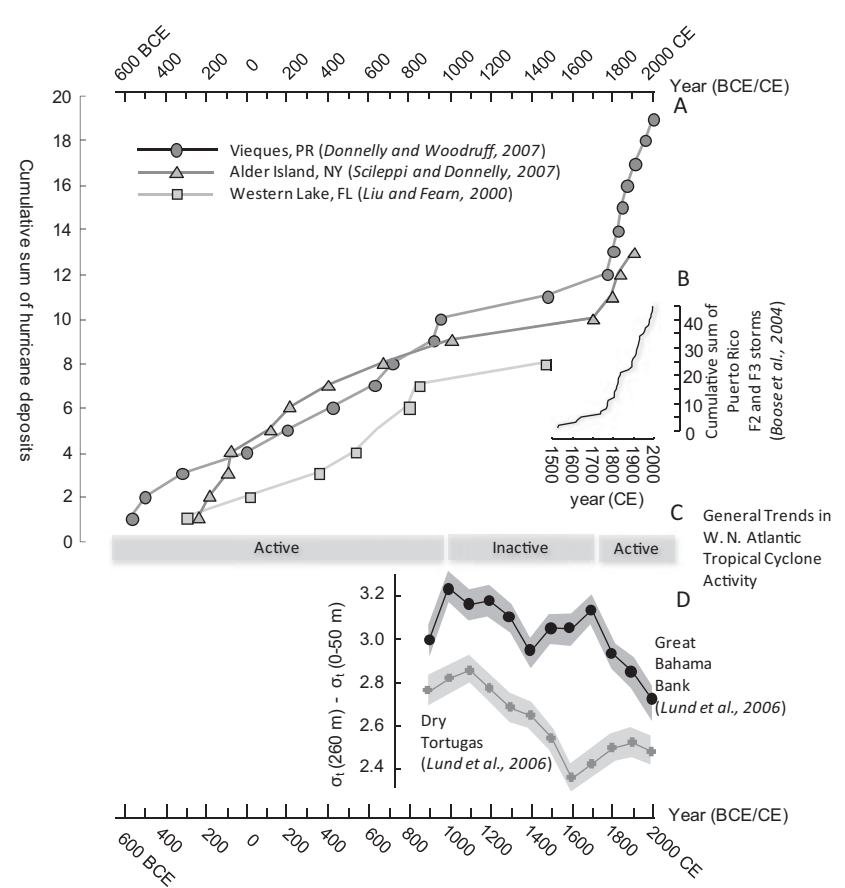

Figure 2. (A) Cumulative number of TC-induced overwash layers since 600 BCE identified at: Vieques, PR, Alder Island, NY, and Western Lake, FL with sources for each individual record cited in figure. (B) Cumulative sum of F2 and F3 storms for Puerto Rico (Boose et al., 2004), referenced to the Fujita scale (Fujita, 1971, 1987), and roughly equivalent to category 3 or greater storm TC intensity. (C) General trends in western North Atlantic TC activity based on results presented in A and B. (D) Stratification for Great Bahama Bank (black circles) and Dry Tortugas (gray plus signs) expressed as thermocline density (at $260 \mathrm{~m}$ water depth) minus surface mixed layer density $(0-50 \mathrm{~m})$. Error bars are plus and minus $1 \sigma$. For clarity, 0.5 density units have been subtracted from the Dry Tortugas time series.

resultant decrease in the density of observations. However, these biases notwithstanding, the sharp increase in historical accounts at Puerto Rico around 1700 CE is still of potential significance, given that it is concurrent with a similar increase in storm counts from the entirely independent sediment-based reconstructions at the Vieques site (Fig. 2B).

\section{Paleo-density reconstructions}

To assess the potential impacts of reduced TC-related mixing prior to $1700 \mathrm{CE}$ on upper ocean stratification we employ results from Lund et al. (2006), who present millennial-scale paleo-density reconstructions based on benthic foraminifera from five separate water depths at Great Bahama Bank (i.e. $700 \mathrm{~m}, 530 \mathrm{~m}, 440 \mathrm{~m}, 260 \mathrm{~m}$, and the surface mixed layer from 0 to $50 \mathrm{~m}$ ). A complete description of the sediment processing, stable isotope, and chronological methods is given in Lund et al. (2006). Here we provide an abbreviated methodology.

The oxygen stable isotopic ratio of foraminifera, expressed as $\delta^{18} \mathrm{O}$, depends on the temperature and $\delta^{18} \mathrm{O}$ of seawater $\left(\delta^{18} \mathrm{O}_{w}\right)$ in which they live. Because $\delta^{18} \mathrm{O}_{w}$ is linearly related to salinity, and the difference between foraminiferal $\delta^{18} \mathrm{O}$ and $\delta^{18} \mathrm{O}_{\mathrm{w}}$ is thermodynamically controlled, seawater density $\left(\sigma_{\mathrm{t}}\right)$ can be estimated using $\delta^{18} \mathrm{O}$ (Lynch-Stieglitz et al., 1999). Sediments collected from a given water depth contain both benthic (sea-floor-dwelling) and planktonic (surface-oceandwelling) foraminifera. Planktonic foraminiferal $\delta^{18} \mathrm{O}$ can therefore be used to constrain $\sigma_{\mathrm{t}}$ for the surface mixed layer, while benthic species provide $\sigma_{t}$ constraints at thermocline depths. Where sloping bathymetry permits, paleo-density profiles can be created using the $\delta^{18} \mathrm{O}$ from benthic formanifera collected at targeted depths in combination with mixed-layer $\delta^{18} \mathrm{O}$ values derived from planktonic foraminifera.

A relatively good agreement has been shown between direct water column measurements of seawater density $\left(\sigma_{t}\right)$ off of Great Bahamas Bank and $\delta^{18} \mathrm{O}$-derived $\sigma_{\mathrm{t}}$ values reconstructed from modern foraminifera in recently deposited sediments from the western slope of Great Bahama Bank (Lund et al., 2006). Supported by this correlation Lund et al. (2006) presents a time series of stratification from Great Bahama Bank extending back to $800 \mathrm{CE}$, and expressed as the difference between $\sigma_{\mathrm{t}}$ values just below the mixed layer at $260 \mathrm{~m}$ and $\sigma_{\mathrm{t}}$ values in the mixed layer (Fig. 2D). Further, a subset of vertical profiles from Lund et al. (2006) of foraminiferal-derived seawater density progressing back into the LIA is presented in Fig. 3(A). Theoretical age resolutions for each sediment sample is 1550 years, but biological mixing of the sediments degrades the resolution such that each represents a multidecadal to centuryscale average. As expected, the vertical density profiles in Fig. 3(A) show that density increases with water depth for each time interval. These profiles also reveal more subtle changes in water column stratification when expressed as the $\sigma_{\mathrm{t}}$ anomaly relative to present (Fig. 3B). For example, the surface layer $\sigma_{t}$ anomaly exhibits a clear monotonic drop to $-0.3 \mathrm{~kg} \mathrm{~m}^{-3}$ when extended to $1600-1700 \mathrm{CE}$, while the $\sigma_{\mathrm{t}}$ anomaly below the mixed layer at a water depth of $260 \mathrm{~m}$ during this same period increases to approximately $+0.1 \mathrm{~kg} \mathrm{~m}^{-3}$ (Fig. 3B). This decrease in surface water density towards the LIA combined with the increase in densities below the mixed layer implies that water column stratification at Great Bahama Bank was greater prior to $1700 \mathrm{CE}$ (Fig. 2D). Variability in vertical stratification at Great Bahama Bank is broadly consistent with changes in TC frequency inferred from overwash deposits, particularly with respect to reconstructions obtained just to the east of the site at Vieques, PR (Fig. 2A and B). Specifically, the general shift towards reduced TC frequency prior to 1700 CE (Fig. 2C) occurs contemporaneously with an increase in vertical stratification at Great Bahama Bank (Fig. 2D).

The only other available record of centennial-scale changes in vertical stratification in the North Atlantic is from near Dry Tortugas (Lund et al., 2006). Like the Great Bahama Bank site, this location is subject to vertical mixing from TCs and displays a prolonged interval of anomalously high vertical stratification relative to present during a pronounced drop in TC activity between 1000 CE and 1500 CE (Fig. 2D). Unlike Great Bahama Bank, however, the Dry Tortugas record displays a minimum in water column stratification around $1600 \mathrm{CE}$, followed by a gradual increase towards present levels of stratification. The discrepancy between the Great Bahama Bank and Dry Tortugas sites after 1600 CE is approximately coeval with the discrepancy in overwash records from the western North Atlantic and Gulf of Mexico, where the New York and Vieques records exhibit an anomalous increase in activity, while the Western Lake, FL record (Fig. 2A) and recent results by Lane et al. (2011) both support relatively quiescent conditions in the northern Gulf of Mexico. Increased TC-induced mixing in the western North Atlantic relative to the Gulf of Mexico following roughly $1600 \mathrm{CE}$ may therefore help to explain observed discrepancies in stratification between the Great Bahama Bank and Dry Tortugas sites. Further, the reduced stratification during $1600 \mathrm{CE}$ at the Dry Tortugas site is due primarily to anomalously high surface salinity, rather than a decrease in salinity at depth due to an increase in vertical mixing. This observation suggests that factors other than TC variability could also be responsible for the 1600 CE minimum in stratification at Dry Tortugas, such as previously cited mechanisms associated with a southward migration of the 


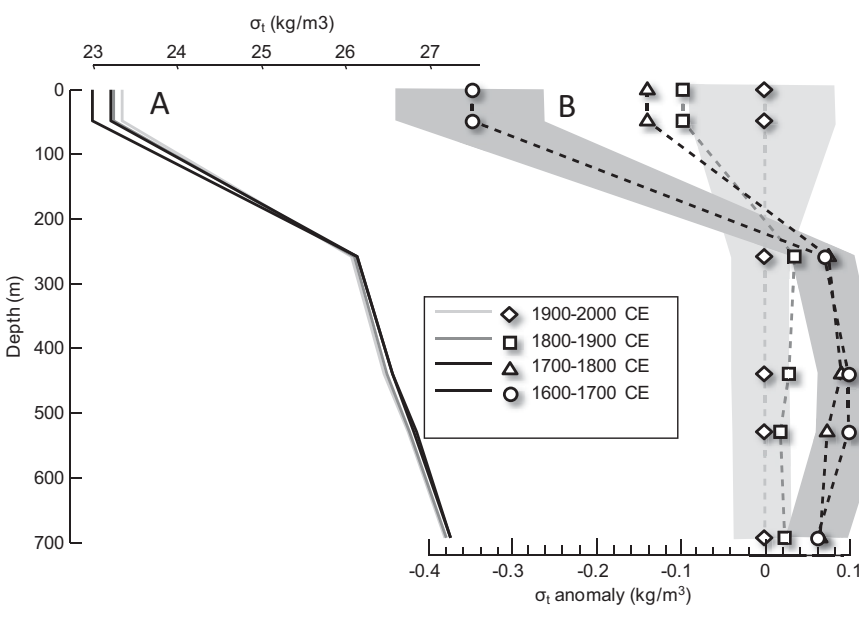

Paleo-Density Reconstructions (Data from Lund et al., 2006)

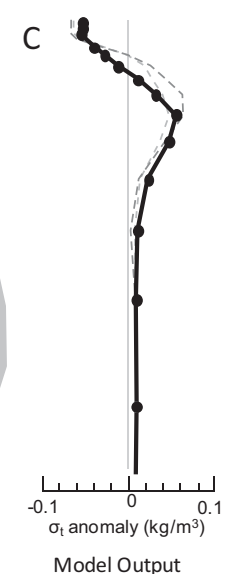

(Data from Sriver and Huber, 2010)
Figure 3. (A) Centennial averaged vertical ocean density profiles near Great Bahama Bank since 1600 CE (solid lines) from Lund et al. (2006), and (B) respective density profile anomalies relative to the 20th century (dashed lines with markers). Error estimates for the mixed layer and thermocline anomalies are $\pm 0.10 \mathrm{~kg} \mathrm{~m}^{-3}$ and $\pm 0.06 \mathrm{~kg} \mathrm{~m}^{-3}$, respectively $(1 \sigma)$, and are presented for reference as gray shading on anomaly profiles for the 17th and 20th centuries. (C) Density anomaly depth profiles from idealized ocean model simulations for control scenario (without TCs), relative to simulations that includes TC forcing closest to present-day levels. Anomaly profile for the grid point closest to Great Bahama Bank is shown in black. Spatially averaged profiles across the Gulf Stream at the Bahaman latitude and the larger western boundary region are shown as dashed dark gray and light gray lines, respectively (see Fig. 1 for averaging boundaries).
Atlantic Intertropical Convergence Zone (ITCZ) (Lund and Curry, 2006).

It is also possible that changes in the $\delta^{18} \mathrm{O}_{w}$-salinity relationship account for density anomalies during the last millennium; however, the evidence available does not support this interpretation. For example, multiple paleoclimate reconstructions from the North Atlantic suggest surface temperatures were about $1^{\circ} \mathrm{C}$ cooler during the Little Ice Age (e.g. Dahl-Jensen et al., 1998; Marchitto and deMenocal, 2003). Based on the spatial relationship between temperature and the $\delta^{18} \mathrm{O}$ of precipitation (Dansgaard, 1964), this would imply a $\sim 1 \%$ decrease in the fresh end-member, and a steeper $\delta^{18} \mathrm{O}_{\mathrm{w}}$-salinity slope. The net effect of this change would be to increase thermocline density during the LIA and therefore amplify the reconstructed density anomaly rather than decrease it. The LIA thermocline anomalies could also be eliminated if the fresh end-member were 3\% more enriched than today but this scenario is unlikely given cooler high latitude temperatures. Even if the greater thermocline $\delta^{18} \mathrm{O}$ (and hence $\sigma_{\mathrm{t}}$ could be accounted for with a different $\delta^{18} \mathrm{O}_{w}-\mathrm{S}$ relationship, we are left to explain $\delta^{18} \mathrm{O}$ in the surface mixed layer whece the signal is the reverse of that at depth. Therefore, the simplest interpretation is that the presented $\delta^{18} \mathrm{O}$ time series reflect real changes in seawater density. Further, the reconstructed thermocline anomalies are likely minimum estimates given plausible changes in $\delta^{18} \mathrm{O}_{\mathrm{w}}$ during the LIA.

\section{Model sensitivity experiments}

Comparisons between proxy records for oceanographic stratification at Great Bahama Bank and TC landfalls at the nearby Vieques, PR site present a qualitative connection between a prolonged period of reduced regional TC activity prior to $1700 \mathrm{CE}$ and a concurrent increase in water column stratification (Fig. 2). To further assess whether this relationship is feasible, we present numerical results initially run by Sriver and Huber (2010) to quantify differences in ocean density structure for simulations with and without TC surface wind forcing. Simulations were performed using the ocean component of the Community Climate System Model (CCSM3) (Collins et al., 2006), using the low-resolution configuration (100 zonal and 116 meridional grid points, with 25 vertical levels). Current-day levels of TC activity are simulated using globally gridded TC wind fields, derived from NASA's Quick Scatterometer (QuickScat), and blended into a standard bulk forcing surface input dataset (Large and Yeager, 2004). TC model runs include all cyclone events from 2000 to 2006, as defined by the Best Track datasets (Landsea et al., 2004), with simulations run for 1000 years, which is sufficiently long to achieve near-equilibrium conditions within the uppermost $1000 \mathrm{~m}$.

Limitations associated with the TC simulations by Sriver and Huber (2010) include: (i) use of a coarse-resolution ocean model; (ii) lack of ocean-atmosphere coupling; and (iii) incomplete equilibration of the deep ocean. It is also highly unlikely that TC activity was completely quiescent prior to $1700 \mathrm{CE}$; thus the model control scenario that excludes TC activity completely represents a more extreme case than TC conditions during the LIA. Keeping these caveats in mind, the sensitivity experiments by Sriver and Huber (2010) still serves as a useful exercise to explore how general changes in transient TC mixing processes can influence the mean state of the upper ocean. Comparisons between these model runs and the paleo-reconstructions by Lund et al. (2006) therefore provide a means to evaluate the rough order of magnitude in which reduced TC mixing is capable of affecting variability observed within paleo-density reconstructions.

Figure $3(\mathrm{C})$ illustrates the modeled time-mean anomalous density profile at the grid point closest to the Great Bahama Bank location for no TC mixing (i.e. the control scenario), relative to simulations that best represent present day TC activity. To first test whether density effects from TC-induced mixing at the Great Bahama Bank location is a robust representation for the region, we compare modeled stratification at the site with spatially averaged values for larger regions of the northwestern Atlantic. The same general range of variability between simulations with and without TC winds (i.e. control minus the TC case) is observed for expanding spatial scales, including when spatially averaged both across the Gulf Stream at the Bahama latitude, and the larger western boundary region. Thus the marked agreement between model profiles at Great Bahama Bank and the larger spatial averages support the robustness of the anomalous TC-induced density signal at Great Bahama Bank in indicating large-scale properties of the western North Atlantic, rather than a local regional bias in the model.

In addition to more direct impacts of TC mixing on vertical stratification, it is possible that TC variability may also indirectly influence density at the Great Bahama Bank site through modification of Gulf Stream properties. However, our modeling results do not support this mechanism as a primary driver for 

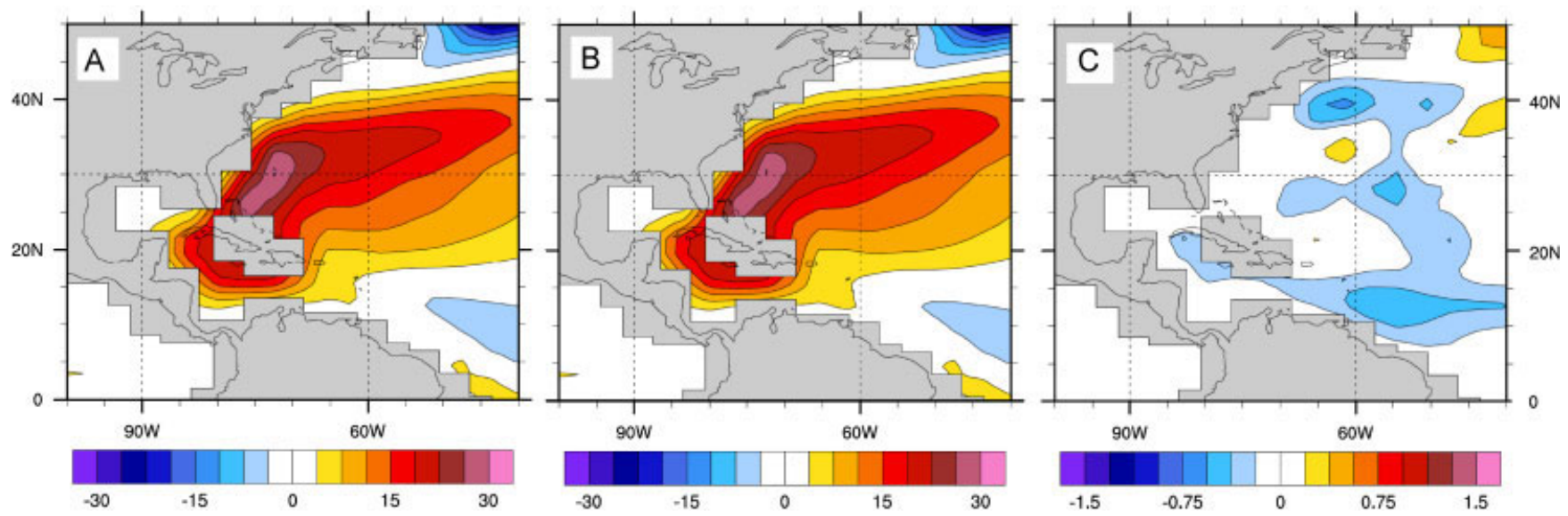

Figure 4. Modeled barotropic stream functions for the North Atlantic region for model simulations performed by Sriver and Huber (2010). (A) Case with TC winds. Units are in sverdrups $\left(1 \mathrm{~Sv}=10^{6} \mathrm{~m}^{3} \mathrm{~s}^{-1}\right)$. (B) Same as A, but for control scenario without TC winds. (C) Difference between the cases shown in $A$ and $B$. Very little change is observed between the two scenarios.

changes in density structure, with no significant difference in the mean characteristics of the Gulf Stream between model cases with and without TC wind forcing (Fig. 4). Thus TC mixing in the model does not appear to alter the mean strength or location of the wind-driven subtropical gyre.

\section{Model data comparison}

The influence of TC-induced mixing is readily observable in the modeled density anomaly profiles (Fig. 3C), with trends similar to those observed within the paleo-density reconstructions by Lund et al. (2006) (Fig. 3B), although moderately smaller in size. Reducing TC wind forcing decreases ocean density within the top $100 \mathrm{~m}$ while increasing ocean density beneath $100 \mathrm{~m}$, thus shallowing the mixed layer and increasing stratification for the control case. This effect is caused primarily by reduced wind-induced vertical mixing, which diminishes the entrainment of cold water through the base of the mixed layer while decreasing warm surface water mixing down into the thermocline.

Both numerically simulated and proxy profiles for vertical density at Great Bahama Bank under reduced TC activity exhibit negative anomalies in the mixed layer and positive anomalies below. An anomaly of roughly $0.12 \mathrm{~kg} \mathrm{~m}^{-3}$ in vertical stratification occurs above and below the mixed layer for model runs with and without TC mixing, which is roughly $25 \%$ of the entire paleo-density anomaly observed just prior to 1700 CE relative to present (Figs 2D and 3B). The modeled seawater density anomaly directly below the mixed layer for the control case relative to current TC activity (roughly $0.06 \mathrm{~kg} \mathrm{~m}^{-3}$, Fig. $3 \mathrm{C}$ ), is also similar to anomalies observed in the paleo-record below the mixed layer during the LIA (roughly $0.10 \pm 0.06 \mathrm{~kg} \mathrm{~m}^{-3}$, Fig. 3B). Profiles for the control simulation without TC-induced mixing and proxy records during the LIA also both exhibit a negative density anomaly at the surface (Fig. 3B and C); however, proxy-based LIA anomalies of approximately $-0.35 \pm 0.10 \mathrm{~kg} \mathrm{~m}^{-3}$ are observed in the surface mixed layer compared to a significantly smaller modeled anomaly of roughly $-0.06 \mathrm{~kg} \mathrm{~m}^{-3}$ for the control simulation.

Vertical changes in density for model simulations without TC-induced mixing are structured somewhat differently from paleo-observations during the LIA. First, the transition from negative surface anomalies to deeper positive density anomalies occurs at a water depth of $\sim 100 \mathrm{~m}$ in the model, compared to a depth of $\sim 200 \mathrm{~m}$ in the paleo-density data. However, the observed depth of $200 \mathrm{~m}$ is based on a linear interpolation of sampling depths at $50 \mathrm{~m}$ and $260 \mathrm{~m}$, with the lack of observations between these two points potentially helping to explain this particular model/data discrepancy. Model results also indicate that mixing associated with TCs primarily affect the upper $300-400 \mathrm{~m}$ of the water column, while higher LIA density anomalies are observed to exist well below this depth, although error estimates for benthic anomalies $\left( \pm 0.06 \mathrm{~kg} \mathrm{~m}^{-3}\right)$ suggest results at a water depth of $700 \mathrm{~m}$ are not statistically different from zero (Fig. 3B).

TC-induced mixing is naturally one of several factors that can influence seawater density at the Great Bahama Bank site, with model/data discrepancies suggesting an ensemble of processes contributing to increased stratification during the LIA. Indeed, Lund and Curry (2006) hypothesize that the reduced influence of saline water from the North Atlantic subtropical gyre due to a southward shift of the ITCZ likely served to decrease surface salinity at Great Bahama Bank during the LIA.

Additionally, density could also respond to altered vertical mixing or varying boundary conditions in the ventilated thermocline region. Our intention here is not to exclude other mechanisms as potential drivers for observed variability in ocean paleo-stratification, but rather to put forth TC mixing as an additional contributor capable of forcing density changes at roughly the same order of magnitude as variability observed during the past millennium.

\section{Conclusion}

Foraminiferal records provide observational evidence that upper ocean density structure near Great Bahama Bank has changed during the past millennium. Specifically, this region exhibited stronger stratification between roughly 1000 and $1700 \mathrm{CE}$, which is roughly concurrent with the LIA. A general decrease in the number of TCs affecting the western North Atlantic relative to present also occurs during this same time interval. On the basis of this correlation we present a potential link between reduced TC mixing and observed centennial changes to the vertical structure of the tropical western North Atlantic. A coarse-resolution ocean model sensitivity experiment provides a further assessment of this potential connection. The model can explain roughly $25 \%$ of the total anomaly in vertical paleo-density when driven without TC surface wind forcing. Modeling results therefore suggest that TC mixing alone cannot completely explain the entire density anomaly observed during the LIA, but do support TC variability as an important and feasible contributor to enhancing oceanic stratification during this interval. 
Acknowledgements. J. D. Woodruff gratefully acknowledges support from the National Science Foundation (OCE Grant \#0902889). R. Sriver's research was funded by the NOAA Climate and Global Change Postdoctoral Fellowship Program, administered by the University Corporation for Atmospheric Research.

Abbreviations. ITCZ, Intertropical Convergence Zone; LIA, Little Ice Age; MCA, Medieval Climate Anomaly; TC, tropical cyclone.

\section{References}

Bender MA, Knutson TR, Tuleya RE, et al. 2010. Modeled impact of anthropogenic warming on the frequency of intense Atlantic hurricanes. Science 327: 454-458.

Besonen MR, Bradley RS, Mudelsee M, et al. 2008. A 1,000-year, annually-resolved record of hurricane activity from Boston, Massachusetts. Geophysical Research Letters 35: L14705.

Boldt KV, Lane P, Woodruff JD, et al. 2010. Calibrating a sedimentary record of overwash from Southeastern New England using modeled historic hurricane surges. Marine Geology 275: 127-139.

Boose ER, Chamberlin KE, Foster DR. 2001. Landscape and regional impacts of hurricanes in New England. Ecological Monographs 71: 27-48.

Boose ER, Serrano MI, Foster DR. 2004. Landscape and regional impacts of hurricanes in Puerto Rico. Ecological Monographs 74: 335-352.

Bove MC, Elsner JB, Landsea CW, et al. 1998. Effect of El Niño on US landfalling hurricanes, revisited. Bulletin of the American Meteorological Society 79: 2477-2482.

Brierley CM, Fedorov AV, Liu Z, et al. 2009. Greatly expanded tropical warm pool and weakened Hadley circulation in the early Pliocene. Science 323: 1714-1718.

Brooke B, Ryan D, Pietsch T, et al. 2008. Influence of climate fluctuations and changes in catchment land use on Late Holocene and modern beach-ridge sedimentation on a tropical macrotidal coast: Keppel Bay, Queensland, Australia. Marine Geology 251: 195-208.

Buynevich IV, FitzGerald DM, Goble RJ. 2007. A 1500 yr record of North Atlantic storm activity based on optically dated relict beach scarps. Geology 35: 543-546.

Chan JCL, Shi J. 2000. Frequency of typhoon landfall over Guangdong Province of China during the period 1470-1931. International Journal of Climatology 20: 183-190.

Chenoweth M. 2006. A reassessment of historical Atlantic basin tropical cyclone activity, 1700-1855. Climatic Change 76: 169-240.

Chenoweth M, Divine D. 2008. A document-based 318-year record of tropical cyclones in the Lesser Antilles, 1690-2007. Geochemistry Geophysics Geosystems 9: Q08013.

Collins WD, Bitz CM, Blackmon ML, et al. 2006. The community climate system model version 3 (CCSM3). Journal of Climate 19: 2122-2143.

Dahl-Jensen D, Mosegaard K, Gundestrup N, et al. 1998. Past temperatures directly from the Greenland ice sheet. Science 282: 268 271.

Dansgaard W. 1964. Stable isotopes in precipitation. Tellus 16: 436468.

Donnelly JP, Webb T. 2004. Back-barrier sedimentary records of intense hurricane landfalls in the northeastern United States. In Hurricanes and Typhoons: Past, Present and Future, Murnane R, Liu KB (eds). Columbia University Press: New York; 58-96.

Donnelly JP, Woodruff JD. 2007. Intense hurricane activity over the past 5,000 years controlled by El Niño and the West African monsoon. Nature 447: 465-468.

Donnelly JP, Bryant SS, Butler J, et al. 2001a. 700 yr sedimentary record of intense hurricane landfalls in southern New England. Geological Society of America Bulletin 113: 714-727.

Donnelly JP, Roll S, Wengren M, et al. 2001b. Sedimentary evidence of intense hurricane strikes from New Jersey. Geology 29: 615618.

Donnelly JP, Butler J, Roll S, et al. 2004. A backbarrier overwash record of intense storms from Brigantine, New Jersey. Marine Geology 210: 107-121.

Elsner JB, Kossin JP, Jagger TH. 2008. The increasing intensity of the strongest tropical cyclones. Nature 455: 92-95.
Emanuel K. 2001. Contribution of tropical cyclones to meridional heat transport by the oceans. Journal of Geophysical Research-Atmospheres 106: 14771-14781.

Emanuel K. 2005. Increasing destructiveness of tropical cyclones over the past 30 years. Nature 436: 686-688.

Emanuel K, Sundararajan R, Williams J. 2008. Hurricanes and global warming: results from downscaling IPCC AR4 simulations. Bulletin of the American Meteorological Society 89: 347-367.

Emanuel K, Oouchi K, Satoh M, et al. 2010. Comparison of explicitly simulated and downscaled tropical cyclone activity in a highresolution global climate model. Journal of Advances in Modeling Earth Systems 2: 1-9.

Fedorov A, Brierley C, Emanuel K. 2010. Tropical cyclones and permanent El Niño in the early Pliocene epoch. Nature 463: 1066-1070.

Fogarty EA, Elsner JB, Jagger TH, et al. 2006. Variations in typhoon landfalls over China. Advances in Atmospheric Sciences 23: 665677

Frappier A, Knutson T, Liu KB, et al. 2007a. Perspective: coordinating paleoclimate research on tropical cyclones with hurricane-climate theory and modelling. Tellus A 59: 529-537.

Frappier AB, Sahagian D, Carpenter SJ, et al. 2007b. Stalagmite stable isotope record of recent tropical cyclone events. Geology 35: 111114

Fujita TT. 1971. Proposed characterization of tornadoes and hurricanes by area and intensity. In SMRP (Satellite and Mesometeorology Research Project) Research Paper 91. University of Chicago: Chicago, IL.

Fujita TT. 1987. US tornadoes. Part 1: 70-year statistics (Satellite and Mesometeorology Research Project) Research Paper 218. University of Chicago Press: Chicago, IL.

Garcia-Herrera R, Gimeno L, Ribera P, et al. 2005. New records of Atlantic hurricanes from Spanish documentary sources. Journal of Geophysical Research 110: D02109.

Garcia-Herrera R, Ribera P, Hernandez E, et al. 2007. Northwest Pacific typhoons documented by the Philippine Jesuits, 1566-1900. Journal of Geophysical Research 112: D06108.

Goldenberg SB, Landsea CW, Mestas-Nunez AM, et al. 2001. The recent increase in Atlantic hurricane activity: causes and implications. Science 293: 474-479.

Gray WM. 1984. Atlantic seasonal hurricane frequency. Part I: El Niño and $30 \mathrm{mb}$ quasi-biennial oscillation influences. Monthly Weather Review 112: 1649-1668.

Grossman MJ. 2001. Large floods and climatic change during the Holocene on the Ara River, Central Japan. Geomorphology 39: 21-37.

Grossman MJ, Zaiki M. 2007. Reconstructing typhoon landfalls in Japan using historical documents: 1801-1830. Papers and Proceedings of Applied Geography Conferences 30: 334-343.

Hippensteel SP, Martin RE. 1999. Foraminifera as an indicator of overwash deposits, barrier island sediment supply, and barrier island evolution: Folly Island, South Carolina. Palaeogeography, Palaeoclimatology, Palaeoecology 149: 115-125.

Jansen M, Ferrari R. 2009. Impact of the latitudinal distribution of tropical cyclones on ocean heat transport. Geophysical Research Letters 36: L06604.

Knutson TR, Sirutis JJ, Garner ST, et al. 2008. Simulated reduction in Atlantic hurricane frequency under twenty-first-century warming conditions. Nature Geoscience 1: 359-364.

Korty RL, Emanuel KA, Scott JR. 2008. Tropical cyclone-induced upperocean mixing and climate: application to equable climates. Journal of Climate 21: 638-654.

Landsea CW, Anderson C, Charles N, et al. 2004. The Atlantic hurricane database reanalysis project: Documentation for 1851 1910 alterations and addition to the HURDAT database. In Hurricanes and Typhoons: Past, Present and Future, Murnane R, Liu KB (eds). Columbia University Press: New York; 178-221.

Landsea CW, Vecchi GA, Bengtsson L, et al. 2010. Impact of duration thresholds on Atlantic tropical cyclone counts. Journal of Climate 23: 2508-2519.

Lane P, Donnelly JP, Woodraff JD, et al. 2011. A decadally-resolved paleohurricane record archived in the late Holocene sediments of a Florida sinkhole. Marine Geology 287: 14-30. 
Large WG, Yeager SG. 2004. Diurnal to decadal global forcing for ocean and sea-ice models: the data sets and flux climatologies. NCAR Tech Note NCAR/TN-460+STR.

Liu KB, Fearn ML. 1993. Lake-sediment record of late Holocene hurricane activities from coastal Alabama. Geology 21: 793-796.

Liu KB, Fearn ML. 2000. Reconstruction of prehistoric landfall frequencies of catastrophic hurricanes in northwestern Florida from lake sediment records. Quaternary Research 54: 238-245.

Liu K, Shen C, Louie K. 2001. A 1,000-year history of typhoon landfalls in Guangdong, southern China, reconstructed from Chinese historical documentary records. Annals of the Association of American Geographers 91: 453-464.

Lough JM. 2007. Tropical river flow and rainfall reconstructions from coral luminescence: Great Barrier Reef, Australia. Paleoceanography 22: PA2218.

Ludlum DM. 1963. Early American Hurricanes: 1492-1870. American Meteorological Society: Boston, MA.

Lund DC, Curry W. 2006. Florida Current surface temperature and salinity variability during the last millennium. Paleoceanography 21: PA2009.

Lund DC, Lynch-Stieglitz J, Curry WB. 2006. Gulf Stream density structure and transport during the past millennium. Nature 444: 601-604.

Lynch-Stieglitz J, Curry WB, Slowey N. 1999. A geostrophic transport estimate for the Florida Current from the oxygen isotope composition of benthic foraminifera. Paleoceanography 14: 360-373.

Malmquist D. 1997. Oxygen isotopes in cave stalagmites as a proxy record of past tropical cyclone activity. In 22nd Conference on Hurricanes and Tropical Meteorology. American Meteorological Society, Fort Collins, CO; 393-394.

Mann ME, Sabbatelli TA, Neu U. 2007. Evidence for a modest undercount bias in early historical Atlantic tropical cyclone counts. Geophysical Research Letters 34: L22707.

Mann M, Woodruff J, Donnelly J, et al. 2009. Atlantic hurricanes and climate over the past 1,500 years. Nature 460: 880-883.

Marchitto TM, deMenocal PB. 2003. Late Holocene variability of upper North Atlantic Deep Water temperature and salinity. Geochemistry, Geophysics, Geosystems 4: 1100.

McCloskey T, Keller G. 2009. 5000 year sedimentary record of hurricane strikes on the central coast of Belize. Quaternary International 195: 53-68.

Miller DL, Mora Cl, Grissino-Mayer HD, et al. 2006. Tree-ring isotope records of tropical cyclone activity. Proceedings of the National Academy of Sciences USA 103: 14294-14297.

Mock C. 2004. Tropical cyclone reconstructions from documentary records: examples from South Carolina. In Hurricanes and Typhoons: Past, Present and Future, Murnane R, Liu KB (eds). Columbia University Press: New York; 121-148.

Mock C. 2008. Tropical cyclone variations in Louisiana, USA, since the late eighteenth century. Geochemistry Geophysics Geosystems 9: Q05V02.

Noren AJ, Bierman PR, Steig EJ, et al. 2002. Millennial-scale storminess variability in the northeastern United States during the Holocene epoch. Nature 419: 821-824.

Nott J. 2004. Palaeotempestology: the study of and implications. Review article: prehistoric tropical cyclones-a review for hazard assessment. Environment International 30: 433-447.

Nott J. 2011. A 6000 year tropical cyclone record from Western Australia. Quaternary Science Reviews 30: 713-722.

Nott J, Hayne M. 2001. High frequency of 'super-cyclones' along the Great Barrier Reef over the past 5,000 years. Nature 413: 508512.

Nott J, Haig J, Neil H, et al. 2007. Greater frequency variability of landfalling tropical cyclones at centennial compared to seasonal and decadal scales. Earth and Planetary Science Letters 255: 367372.
Nott J, Smithers S, Walsh K, et al. 2009. Sand beach ridges record 6000 year history of extreme tropical cyclone activity in northeastern Australia. Quaternary Science Reviews 28: 1511-1520.

Nyberg J, Malmgren BA, Winter A, et al. 2007. Low Atlantic hurricane activity in the 1970s and 1980s compared to the past 270 years. Nature 447: 698-701.

Scheffers A, Scheffers S. 2006. Documentation of the impact of Hurricane Ivan on the coastline of Bonaire (Netherlands Antilles). Journal of Coastal Research 22: 1437-1450.

Scileppi E, Donnelly JP. 2007. Sedimentary evidence of hurricane strikes in western Long Island, New York. Geochemistry Geophysics Geosystems 8: Q06011.

Scott D, Collins E, Gayes P, et al. 2003. Records of prehistoric hurricanes on the South Carolina coast based on micropaleontological and sedimentological evidence, with comparison to other Atlantic Coast records. Geological Society of America Bulletin 115: 1027-1039.

Spiske M, Borocz Z, Bahlburg H. 2008. The role of porosity in discriminating between tsunami and hurricane emplacement of boulders: a case study from the Lesser Antilles, southern Caribbean. Earth and Planetary Science Letters 268: 384-396.

Sriver RL, Huber M. 2007. Observational evidence for an ocean heat pump induced by tropical cyclones. Nature 447: 577-580.

Sriver RL, Huber M. 2010. Modeled sensitivity of upper thermocline properties to tropical cyclone winds and possible feedbacks on the Hadley circulation. Geophysical Research Letters 37: L08704.

Sriver RL, Huber M, Nusbaumer J. 2008. Investigating tropical cycloneclimate feedbacks using the TRMM Microwave Imager and the Quick Scatterometer. Geochemistry Geophysics Geosystems 9: Q09V11.

Sriver RL, Goes M, Mann ME, et al. 2010. Climate response to tropical cyclone-induced ocean mixing in an Earth system model of intermediate complexity. Journal of Geophysical Research 115: C10042.

Suzuki A, Yokoyama Y, Kan H, et al. 2008. Identification of 1771 Meiwa Tsunami deposits using a combination of radiocarbon dating and oxygen isotope microprofiling of emerged massive Porites boulders. Quaternary Geochronology 3: 226-234.

Wallace DJ, Anderson JB. 2010. Evidence of similar probablility of intense hurricane strikes for the Gulf of Mexico over the late Holocene. Geology 38: 511-514.

Webster PJ, Holland GJ, Curry JA, et al. 2005. Changes in tropical cyclone number, duration, and intensity in a warming environment. Science 309: 1844-1846.

Williams H. 2010. Storm surge deposition by Hurricane Ike on the McFaddin National Wildlife Refuge, Texas: implications for paleotempestology studies. Journal of Foraminiferal Research 40: 210-219.

Woodruff JD, Donnelly JP, Emanuel K, et al. 2008a. Assessing sedimentary records of paleohurricane activity using modeled hurricane climatology. Geochemistry Geophysics Geosystems 9: Q09V10.

Woodruff JD, Donnelly JP, Mohrig D, et al. 2008b. Reconstructing relative flooding intensities responsible for hurricane-induced deposits from Laguna Playa Grande, Vieques, Puerto Rico. Geology 36: 391-394.

Woodruff JD, Donnelly JP, Okusu A. 2009. Exploring typhoon variability over the mid-to-late Holocene: evidence of extreme coastal flooding from Kamikoshiki, Japan. Quaternary Science Reviews 28: 1774-1785.

Yu K, Zhao J, Shi Q, et al. 2009. Reconstruction of storm/tsunami records over the last 4000 years using transported coral blocks and lagoon sediments in the southern South China Sea. Quaternary International 195: 128-137.

Zhao J, Neil D, Feng Y, et al. 2009. High-precision U-series dating of very young cyclone-transported coral reef blocks from Heron and Wistari reefs, southern Great Barrier Reef, Australia. Quaternary International 195: 122-127. 